\title{
Prognostic factors in 291 patients with pulmonary metastases submitted to thoracotomy
}

\author{
Department of Pelvic Surgery - Hospital A. C. Camargo, \\ Fundação Antonio Prudente - São Paulo, Brazil
}

\begin{abstract}
Pulmonary metastases are among the most common sites for the spread of cancer, particularly with mesenchymal tumors. Despite improvements in cancer therapy, the prognosis remains poor, except for the highly selective group of patients who are considered eligible for surgical treatment and those with chemosensitive tumors. The main objective of this study was to evaluate survival results of 291 patients who underwent thoractomy due to pulmonary metastases between 1953 and 1986 . The number of metastases ranged from a minimum of 1 to as many as 30 . The type of resection depended on site, size, and number of pulmonary lesions: 154 wedge resections, 49 lobectomies, and 9 pneumectomies. The tumor was not resectable in the remaining 79 patients. Of the prognostic factors analyzed, only type of pulmonary resection (wedge vs. lobectomy vs. pneumectomy vs. unresectable) and disease free interval (DFI) between primary treatment and pulmonary metastases diagnosis ( $<=6$ months vs. $7-12$ months vs. $>12$ months) were selected as independent predictors of the risk of death in multivariate analysis. A reduced model for bone tumors included disease free interval, sex and histology.
\end{abstract}

UNITERMS: Survival. Surgery. Prognostic factors. Metastases. Lung.

\section{INTRODUCTION}

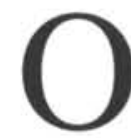
nly a small number of cases that underwent pulmonary metastases resection before 1950 were published, and most of those were lacking detailed information on survival rates and prognostic factors. In 1884 , Kronlein (13) presented the first case of pulmonary

\author{
Address for correspondence: \\ Benedito M. Rossi \\ Hospital A. C. Camargo - Fundação Antonio Prudente \\ Rua Professor Antonio Prudente, 211 \\ São Paulo - SP - Brasil - CEP 01509-010
}

metastases resection from a chest wall sarcoma that was operated simultaneously. In 1926, Divis (8) performed a metachronous pulmonary metastases resection. In 1939, Barney and Churchill (3) resected one pulmonary metastases from a kidney carcinoma. This patient survived 23 years after nefrectomy. In 1947, Alexander and Haight (1) reported good survival results in 3 of 6 patients that underwent pulmonary metastases resection.

Only in the 50's and 60's with the development of surgical and anesthetic techniques did pulmonary resections begin to be performed with more frequency. In spite of the fact that the number of published cases now exceeds 2,000, various controversies about indications and prognostic factors remain (12).

Some important indication factors have to be considered (16): (I) The primary tumor must be under control or able to be controlled; (II) pulmonary metastases 
resection must be technically possible; (III) the patient must not have another site of metastatic lesions; (IV) surgery should be considered only in the absence of a more efficient therapy; (V) the patient must have adequate clinical conditions and pulmonary function to be operated on.

The main objectives of this paper were to evaluate survival results and identify prognostic factors related to pulmonary metastases resection. These results can be used to improve accuracy when evaluating cases eligible for this kind of treatment.

\section{CASEWORK AND METHODOLOGY}

The authors reviewed the records of 291 patients who underwent pulmonary metastases resection at the Department of Pelvic Surgery of A. C. Camargo Hospital, Foundation Antonio Prudente, in São Paulo, Brazil, from January 1953 to December 1986 . These patients represent only a portion of a larger group with clinical diagnosis of pulmonary metastases. Only patients eligible for surgical treatment were considered for this study. The criteria for the indication of surgical treatment was rather uniform during the period of this investigation, specifically: good performance status, no evidence of pleural effusion or mediastinum invasion and absence of a more efficient therapy. Patients were operated on independent of number, size, and location of pulmonary metastases. The histological type of primary tumor was not taken into consideration for treatment. When there was any plausible doubt whether or not the pulmonary lesion was in fact metastatic, the case was excluded from this study.

There were $150(51.5 \%)$ male patients and 141 $(48.5 \%)$ female patients. Ages ranged from 1 to 79 years old, with a median age of 30.5 . The primary tumor locations were: 107 bone ( $36.8 \%), 78$ soft parts $(26.8 \%)$, 46 urogenital ( $15.8 \%$ ), and 45 miscellaneous ( $15.5 \%)$. Two cases had pulmonary recurrence of Hodgkin's disease after chemotherapy and 13 were patients with pulmonary metastases from unknown primary tumors.

All cases were evaluated with chest X-rays. Chest planigraphy was done in 157 cases $(55 \%)$. There were unilateral metastases in 259 cases $(89 \%)$, and $32(11 \%)$ were bilateral. The exact number of metastases was obtained post-surgically. Of the thoractomies there were: 259 cases of posterolateral ( 15 bilateral), 9 bilateral horizontal, 7 trans sternal, and in 16 other types. The resections were one or multiple wedge resections in 154 cases $(52.9 \%)$, lobectomy in 34 cases $(11.7 \%)$, wedge resection plus lobectomy in 15 cases $(5.2 \%)$, and pneumectomy in $9(3.1 \%)$. In 79 cases $(27.1 \%)$ the metastases were not resectable.

The histology of the metastases was the same as the primary tumor in $247(84.9 \%)$, different in $23(7.9 \%)$, not conclusive in $10(3.4 \%)$, and in $11(3.8 \%)$ there was no information on the chart.

Statistical Analysis: product limit estimates of the survival function were used for the computation of cumulative survival rates (11), using the KMSURV program (5). Overall survival was computed on the basis of the dates and events abstracted from the original patient records. This was defined as the interval between the date of the thoractomy and the date of death for uncensored observations.

Cox's regression model was used to estimate the hazard ratio (HR) of death due to the combined effects of two or more study factors (4). This model was also used to build models containing the most restricted subset of variables with independent predictive properties with respect to the risk of death. A stepwise forward algorithm was used for variable selection. Inferences were based on the partial likelihood ratio (deviance) statistic between nested models (10\% significance level). Finally, risk groups were determined on the basis of distribution of combined effects of significant variables, and split into three levels: low risk $(\mathrm{RR}<0.51)$, intermediate risk $(0.51<R R<1.51)$ and high risk $(R R>1.51)$.

\section{RESULTS}

The number of pulmonary metastases ranged from a minimum of 1 (102 cases, $35 \%$ ) to as many as 30 . The exact number of metastases was not reported in 9 cases, $(3 \%)$. At the closing date of the study, there was a total of 6,193 patient-months of cumulative follow-up experience with a 10 month median. During the follow-up period, 74 patients $(25.4 \%)$ were re-operated with further thoractomies: a second thoractomy in 58 cases and a third in 16 cases. One hundred and ninety-six (196) patients died $(67.4 \%)$ due to residual or recurrent cancer or treatment complications $(5.8 \%$ post-operative mortality rate 30 days after first thoractomy) and 5 deaths (1.7\%) due to causes not related to cancer. Nineteen (19) patients were alive $(6.5 \%)$ with recent follow-up information 
Table 1

Cumulative survival rates according to selected characteristics

\begin{tabular}{|c|c|c|c|c|c|c|}
\hline Variable & Categories & \# of cases & Mean survival & Standard error & 5-years survival & $\mathrm{p}$ \\
\hline \multirow[t]{2}{*}{ Age (years) } & $<=16$ & 72 & 33.5 & 5.8 & 20.7 & \multirow[t]{2}{*}{0.9738} \\
\hline & $17-50$ & 142 & 31.1 & 4.0 & 19.0 & \\
\hline$>=51$ & 77 & 32.4 & 5.7 & 18.2 & & \\
\hline \multirow[t]{2}{*}{ Sex } & Male & 150 & 38.1 & 5.4 & 16.8 & \multirow[t]{2}{*}{0.6776} \\
\hline & Female & 141 & 40.0 & 7.5 & 22.1 & \\
\hline \multirow{6}{*}{$\begin{array}{l}\text { DFI (1) prior } \\
\text { to lung } \\
\text { metastases } \\
\text { Tumor location } \\
\text { a) Bone }\end{array}$} & $<=6 \mathrm{mo}$. & 58 & 15.4 & 2.9 & 5.8 & \multirow[t]{4}{*}{0.0007} \\
\hline & 7-12 mo. & 50 & 20.8 & 5.9 & 15.2 & \\
\hline & $>=13 \mathrm{mo}$. & 183 & 28.6 & 2.3 & 23.8 & \\
\hline & & & & & & \\
\hline & No & 184 & 35.35 & 4.1 & 21.2 & \multirow[t]{2}{*}{0.6242} \\
\hline & Yes & 107 & 31.6 & 5.0 & 15.6 & \\
\hline \multirow{6}{*}{$\begin{array}{l}\text { b) Soft } \\
\text { parts } \\
\text { c) Uro- } \\
\text { genital } \\
\text { d) Other }\end{array}$} & No & 213 & 45.9 & 6.1 & 20.1 & \multirow{2}{*}{0.8560} \\
\hline & Yes & 78 & 38.8 & 9.5 & 17.0 & \\
\hline & No & 245 & 47.0 & 6.6 & 17.1 & \multirow[t]{2}{*}{0.6271} \\
\hline & Yes & 46 & 63.1 & 14.4 & 30.1 & \\
\hline & No & 246 & 34.2 & 3.3 & 20.3 & \multirow[t]{2}{*}{0.3428} \\
\hline & Yes & 45 & 26.0 & 6.2 & 13.4 & \\
\hline \multirow{4}{*}{$\begin{array}{l}\text { Type of } \\
\text { resection }\end{array}$} & Wedge & 154 & 46.9 & 0.8 & 27.7 & \multirow[t]{4}{*}{$<0.0001$} \\
\hline & Lobectomy & 49 & 15.0 & 2.3 & 16.3 & \\
\hline & Pneumectomy & 9 & 6.0 & 2.9 & 0.0 & \\
\hline & Unresec. & 79 & 11.5 & 1.1 & 4.3 & \\
\hline \multirow{3}{*}{$\begin{array}{l}\text { Number of } \\
\text { metastases }\end{array}$} & 1 & 102 & 38.8 & 5.3 & 24.5 & \multirow[t]{3}{*}{0.0719} \\
\hline & 2 & 51 & 30.1 & 6.2 & 17.1 & \\
\hline & $>=3$ & 138 & 26.6 & 3.7 & 15.8 & \\
\hline \multirow{2}{*}{$\begin{array}{l}\text { Pre/postop. } \\
\text { chemotherapy }\end{array}$} & No & 159 & 37.1 & 6.6 & 14.6 & \multirow[t]{2}{*}{0.0361} \\
\hline & Yes & 132 & 57.3 & 9.2 & 23.3 & \\
\hline
\end{tabular}

(1) $\mathrm{DFI}=$ disease free interval

available (three of them with recurrent disease). An additional 76 patients $(26.1 \%)$ were considered lost to follow-up, but contributed sufficient information before then to be included in the survival analysis.

Post-operative complications included: respiratory alterations $(7.4 \%)$, metabolic alterations $(4.7 \%)$, cardiovascular alterations and infection $(4.1 \%)$, fistula (1.4\%) and sepsis $(1 \%)$.

Table 1 shows a summary of cumulative survival data for selected characteristics. Demographic variables had no impact on prognosis. Disease free interval (DFI) prior to the detection of pulmonary metastases was significantly associated with patient's outcome. Patients with DFIs longer than 6 and 12 months experienced better survival rates, $(15.2 \%$ and $23.8 \%$ respectively for five year overall survival). The site of the primary tumor did not have significant effect on survival results. The number of metastases and treatment-related factors had a significant impact on survival rates. Rates were better for patients with solitary metastases and those who underwent wedge resections. The positive prognostic effect of pre- and/or post-operative chemotherapy was apparently substantial. However, its indication was remarkably biased by patients performance status and supposed chemosensitivity to the 
tumor. Therefore this variable was omitted from the pool of candidate prognostic factors used to build the Cox models for survival prediction purposes.

Patients with chondrosarcoma and bone tumors other than osteosarcoma had the highest survival rates in this series, with $50 \%$ of 5 -year overall survival rates. On the other hand, the worst results were seen among primary liver cancer and malignant melanoma patients, both groups having no survivors after five years. (Table 2).

Only two of the prognostic factors were selected in the statistical model as independent predictors of the risk of death: the type of pulmonary resection and DFI. The model for bone tumors included DFI, sex and histology. The risk of death due to soft parts tumors was only affected by the number of metastases and DFI (Table 3 ).

A synthetic variable representing the risk of death was calculated using regression coefficients from the multivariate models shown in Table 3 . Patients were subsequently grouped into three empirical risk groups (low, intermediate and high) based on the distribution of the synthetic linear predictors. The cumulative survival distribution for each of these risk groups is shown in figure 1.

\section{DISCUSSION}

The impact of various prognostic factors on survival rates of patients who underwent pulmonary metastases resection has been recognized in the literature.

Though DFI has been shown by various authors $(6,7,9,17,23,24,25,26,27)$ specifically to be the most important prognostic factor, other investigations have not confirmed this fact $(10,18,21)$. In this study, however, DFI emerged as one of the most significant prognostic factors.

Another significant predictor of outcome is the type of pulmonary resection, a variable based on site, size and number of metastases $(19,26)$. In summary, the larger the size of pulmonary metastases, the worse the prognosis, but on the other hand, total curative pneumectomy is still defended by several authors $(6,9,14,16,17)$. Our results indicate that the type of resection was the most important predictor of survival. Patients submitted to wedge resections had a better prognosis.

Regardless of the type of thoractomy, we found that the best access for the whole lung is posterolateral, even

Table 2

Cumulative survival rates according to histopatology of primary tumor

\begin{tabular}{|c|c|c|c|c|c|c|}
\hline Site of tumor & Histology & $\#$ of cases & Mean survival & Standard error & 5-years survival & $p$ \\
\hline \multirow[t]{3}{*}{ Bone } & Osteosarcoma & 96 & 21.5 & 3.1 & 12.9 & \multirow[t]{3}{*}{0.1522} \\
\hline & Chondrosarcoma & 7 & 51.0 & 21.1 & 50.0 & \\
\hline & Other & 4 & 69.9 & 41.1 & 50.0 & \\
\hline \multirow[t]{2}{*}{ Soft parts } & Rhabdomiosa. & 9 & 26.2 & 9.0 & 20.8 & \multirow[t]{2}{*}{0.9649} \\
\hline & Other & 69 & 22.7 & 2.9 & 15.7 & \\
\hline \multicolumn{7}{|l|}{ Urogenital } \\
\hline a) Kidney & Adenoca. & 11 & 22.0 & 14.7 & 31.2 & \multirow[t]{4}{*}{0.7527} \\
\hline b) Uterus & Squamous-cell ca. & 13 & 21.6 & 6.9 & 29.2 & \\
\hline c) Breast & Adenoca. & 8 & 29.2 & 29.1 & 14.6 & \\
\hline d) Other & Various & 14 & 28.0 & 7.5 & 42.2 & \\
\hline \multicolumn{7}{|l|}{ Other } \\
\hline a) Colorectal & Adenoca. & 16 & 12.0 & 1.7 & 22.9 & \multirow[t]{4}{*}{0.1381} \\
\hline b) Liver & Carcinoma & 5 & 8.8 & 2.9 & 0.0 & \\
\hline c) Skin & Melanoma & 7 & 10.6 & 2.5 & 0.0 & \\
\hline d) Head/neck & Carcinoma & 17 & 8.8 & 1.7 & 10.2 & \\
\hline
\end{tabular}


Table 3

Statistical models for the risk of death after surgical treatment of pulmonary metastases

Variable in the model

Terms

Regression coefficient

Standard error

a) Complete model (all sites and histologies):

Type of resection

Lobectomy

0.4274

0.2040

Pneumectomy

1.8516

0.3596

Unresectable

0.8041

0.1783

DFI

6-12

$-0.0584$

0.2392

$>12$

$-0.6639$

0.1875

b) Bone tumors model:

DFI (months)

Sex

Histology
6-12

$>12$

Female

Chondrosarcoma

Other
$-0.5404$

$-1.0752$

0.6820

$-1.0748$

$-0.9409$
0.3078

0.3182

0.2746

0.7244

0.7396

c) Soft parts tumors model:

Number de metastases

2

$-0.0833$

0.3037

$>=3$

DFI (months)

6-12

0.4746

0.2295

$>12$

$-0.0460$

0.3198

$-0.5301$

0.2746

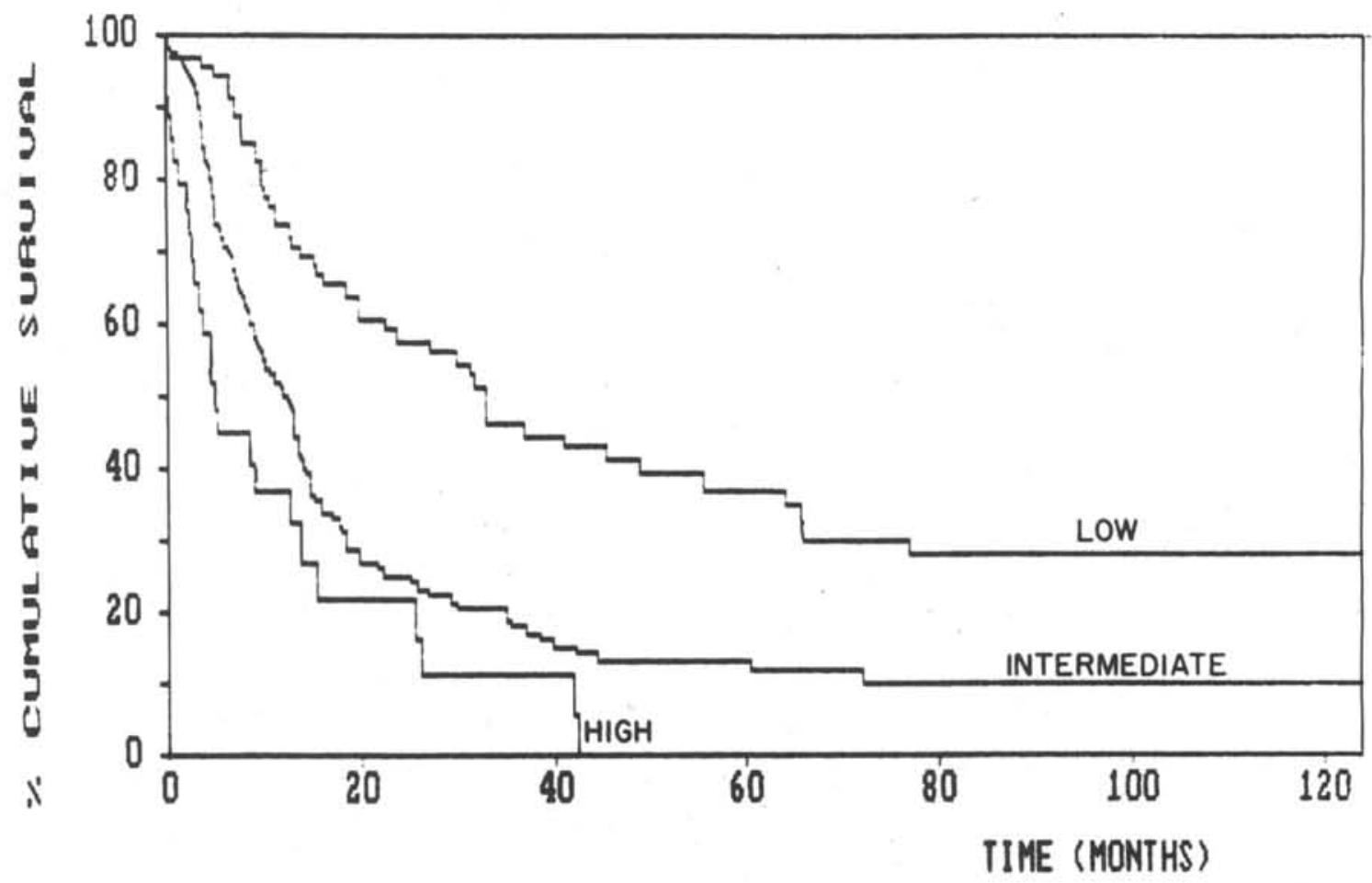

Figure 1 - Cumulative survival distribution for low, intermediate and high risk of death. 
in bilateral lesions. In these cases a sequential bilateral posterolateral thoractomy is indicated.

The number of pulmonary metastases is considered an important prognostic factors by many authors $(6,7,9,16,17,19,20,23,24,25,26,27)$. Other papers dealing with squamous carcinoma of the head and neck $(15,21,25)$ do not confirm those results. In this study the number of resected pulmonary metastases was a significant prognostic factor when solitary lesions were compared with two and three or more. However, patients with good performance status can reach the long term survival category in spite of multiple pulmonary metastases. In our opinion, the total number of metastases should not be considered as an absolute limiting factor for surgery, except when wide pleural dissemination occurs. The same is valid for recurrent lesions, when diagnosed by computerized tomography.

Chemotherapy was a significant prognostic factor in preliminary analysis; however we must bear in mind other possibly confusing variables such as the variety of types of primary tumors and various strategies of chemotherapy used over the 33 year range of the study. In the case of osteosarcoma, for example, chemotherapy has been the first option as a neo-adjuvant therapy for pulmonary metastases for the last 20 years $(15,19)$. Neo-adjuvant and adjuvant chemotherapy have also been used on Wilms' tumors, ovary and testicular carcinoma $(2,7)$. The patients classified as having unresectable pulmonary disease in this study who survived more than 5 years had, in fact, chemosensitive tumors.

Histology and site of primary tumor do not show any significant effect on survival results after pulmonary metastases resection. However, tumors like chondrosarcoma, kidney adenocarcinoma, Wilms' tumor, colorectal carcinoma and uterine cervix carcinoma tended to have a better prognosis. On the other hand, there were no survivors of malignant skin melanoma or primary liver cancer.

Our study confirmed that sex and age do not have a significant effect on survival results $(10,20)$.

In conclusion, patients who have a DFI that is greater than 6 months, and a single lesion that is resectable with wedge surgery have the best prognosis. Histology and site of primary tumor must be analyzed case by case, but we think that surgery is still the only way to offer a last chance of prolonged and comfortable survival for many patients.

\section{RESUMO}

Objetivos: A disseminaçāo neoplásica para os pulmōes é muito comum, principalmente nos tumores primários de origem mesenquimal. Apesar do desenvolvimento do tratamento do câncer, o prognóstico de pacientes com metástases pulmonares continua pobre, exceto para um grupo seleto de pacientes, que são eleitos para o tratamento cirúrgico, e aqueles com maior sensibilidade à quimioterapia. Material e Métodos: O principal objetivo deste estudo é avaliar resultados de tratamento em uma série de 291 pacientes submetidos consecutivamente à toracotomia por metástases pulmonares, entre 1953 e 1986.0 número de metástases variou de 1 a 30 , sendo que o tipo de ressecçāo dependeu da localização, tamanho e número de lesōes puimonares. Foram realizadas 154 ressecçōes em cunha, 49 lobectomias e 9 pneumonectomias. O tumor foi irressecável em 79 casos. Resultados e conclusão: Dos fatores prognósticos analisados, somente o tipo de ressecçāo pulmonar (cunha vs lobectomia vs pneumonectomia vs irressecável) e o intervalo livre de doença (DFI) entre o tratamento do tumor primário e o diagnóstico da metástase pulmonar (menor que 6 meses vs. entre 7 e 12 meses vs. maior que 12 meses) foram fatores independentes selecionados como de risco para óbito em análise multivariada. Uma análise de modelo reduzido para tumores ósseos incluiu intervalo livre de doença, sexo e histologia. 


\section{REFERENCES}

1. ALEXANDER, J.; HAIGHT, C. - Pulmonary resection for solitary metastatic sarcomas and carcinomas. Surg Gynecol Obstet 85: 129-146, 1947.

2. BAINS, M.S.; McCORMACK, P.M.; CVITKOVIC, E.; GOLBEY, R.B.; MARTINI, N. - Results of combined chemosurgical therapy for pulmonary metastases from testicular carcinoma. Cancer 41: 850-853, 1978.

3. BARNEY, J.D.; CHURCHILL, E.D. - Adenocarcinoma of the kidney with metastases to the lung cured by nephrectomy and lobectomy. J Urol 42: 269-276, 1939.

4. CAMPOS FILHO, N.; FRANCO, E.L. - Microcomputer assisted multivariate survival data analysis using Cox's proportional hazards regression model. Comput Methods Programs Biomed 31: 81-87, 1990.

5. CAMPOS FILHO, N.; FRANCO, E.L. - Microcomputer assisted multivariate survival data analysis using KaplanMeyer life table estimators. Comput Methods Programs Biomed 27: 223-228, 1988.

6. CLINE, R.E.; YOUNG, Jr W.G. - Long-term results following surgical treatment of metastatic pulmonary tumors. Am Surg 36: 61-68, 1970.

7. DI LORENZO, M.; COLIN, P.P. - Pulmonary metastases in children: Results of surgical treatment. J Pediatr Surg 23: 762-765, 1988.

8. DIVIS, G. - Ein Beitrag zur operativen Behandlung der Lungengeschwülste. Acta Chir Scand 62: 329-341, 1927.

9. EDLICH, R.F.; SHEA, M.A.; FOKER, J.E.; GRONDIN, C.; CASTANEDA, A.R.; VARCO, R.L. - A review of 26 years' experience with pulmonary resection for metastatic cancer. Dis Chest 49: 587-594, 1966.

10. GOYA, T.; MIYAZAWA, N.; KONDO, H.; TSUCHIYA, R.; NARUKE, T.; SUEMASU, K. - Surgical resection of pulmonary metastases from colectal cancer. Cancer 64: 1418-1421, 1989.

11. KAPLAN, E.L.; MEIER, P. - Nonparametic estimation from imcomplete observations. J. M. Stat Assoc 53: 457-481, 1958.

12. KERN, K.A.; PASS, H.I.; ROTH, J.A. - Surgical treatment of pulmonary metastases. In ROSENBERG, S.A.; Surgical treatment of metastatic cancer. Philadelphia: J.B. Lippincott Co., 69-100, 1987.

13. KRÖNLEIN, R.V. apud VAN DONGEN, J.A.; VAN SLOOTEN, E.A. - The surgical treatment of pulmonary metastases. Cancer Treat Rev 5: 29-48, 1978.
14. MARTINI, N.; BAINS, M.S.; HUVOS, A.G.; BEATIIE Jr. E.J. - Surgical treatment of metastatic sarcoma to the lung. Surg Clin North Am 54: 841-848, 1974.

15. MAZER, T.M.; ROBBINS, K.T.; McMURTREY, M.J.; BYERS, R.M. - Resection of pulmonary metastases from squamous carcinoma of the head and neck. Am J Surg 156: 238-242, 1988.

16. MCCORMACK, P.M. - Surgical resection of pulmonary metastases. Semin Surg Oncol 6: 297-302, 1990.

17. MOUNTAIN, C.F. The basis for surgical resection of pulmonary metastases. Int J Radiat Oncol Biol Phys 1: 749 . 753, 1976.

18. MOUNTAIN, C.F.; KHALIL, K.G.; HERMES, K.E.; FRAZIER, O.H. - The contribution of surgery to the management of carcinomatous pulmonary metastases. Cancer 41: 833-840, 1978.

19. PASTORINO, U.; VALENTE, M.; GASPARINI, M. et al. Lung resection as salvage treatment for metastatic osteosarcoma. Tumori 74: 201-206, 1988.

20. PUTNAM, J.B.; ROTH, J.A. - Prognostic indicators in patients with pulmonary metastases. Semin Surg Oncol 6: 291-296, 1990.

21. RENDINA, E.A.; VICENTIIS, M.; PRIMERANO, G.; MINEO, T.C.; RICCI, C. - Pulmonary resection for metastatic laryngeal carcinoma. J Thorac Cardiovasc Surg 92: 114117, 1986.

22. ROSEN, G.; HUVOS, A.G.; MOSENDE, C. et al. Chemotherapy and thoractomy for metastatic osteogenic sarcoma. Cancer 41: 841-849, 1978.

23. SCHOTT, G.; WEISSMÜLLER, J.; VECERA, E. - Methods and prognosis of the estirpation of pulmonary metastases following tumor nephrectomy. Urol Int 43: 272-274, 1988.

24. TAKITA, H.; EDGERTON, F.; KARAKOUSIS, C.; DOUGLAS, Jr. H.O.; VINCENT, R.G.; BERKLEY, S. Surgical management of metastases to the lung. Surg Gynecol Obstet 152: 191-194, 1981.

25. THOMFORD, N.R., WOOLNER, L.B., CLAGETT, O.T. The surgical treatment of metastatic tumors in the lungs. $\mathbf{J}$ Thorac Cardiovasc Surg 49: 357-363, 1965.

26. WILKINS, E.W.; BURKE, J.F.; HEAD, J.M. - The surgical management of metastatic neoplasms in the lung. $\mathbf{J}$ Thorac Cardiovasc Surg 42: 298-309, 1961.

27. WILKING, N.; PETRELLI, N.J.; HERRERA, L.; REGAL, A.M. MITTELMAN, A. - Surgical resection of pulmonary metastases from colectoral adenocarcinoma. Dis Colon Rectum 28: 562-564, 1985. 